\title{
Beyond the Margins: Identity Fragmentation in Visual Representation in Michel Tournier's La Goutte d'or
}

In the final scene of Michel Tournier's postcolonial novel La Goutte d'or (1986), the protagonist, Idriss, shatters the glass of a Cristobal \& Co. storefront window while operating a jackhammer in the working-class Parisian neighbourhood on the Rue de la Goutte d'or. Glass fragments fly everywhere as the Parisian police arrive. In La Goutte d'or, Tournier explores the identity construction of Idriss through a discussion of the role that visual images play in the development of a twentieth-century consciousness of the "Other." At the beginning of the novel, a French tourist takes a photograph of Idriss during her visit to the Sahara. The boy's quest to reclaim his stolen image leads him from the Sahara to Marseille, and finally to the Rue de la Goutte d'or in Paris. The Rue de la Goutte d'or remains one the most cosmopolitan neighbourhoods of the city.

In Tournier's novel, the goutte d'or also corresponds to a symbolic object: a Berber jewel. It is the jewel that Idriss brings with him, but which he also subsequently loses upon his arrival in Marseille. From the very moment that the French tourist photographs him, a marginalization of Idriss's identity occurs. Marginality, quite literally, refers to the spatial property of a location in which something is situated. Figuratively speaking, marginality suggests something that is on the edges or at the outer limits of social acceptability. In this essay, I explore the construction of the marginalized postcolonial self (the "Other") through an examination of the function of visual representation in the development of a postcolonial identity in La Goutte d'or. In the end, I conclude that the construction of a postcolonial identity is based upon fragmentation and marginalization, which ultimately leads its subject to create an identity based upon false constructions. 
L'image est donée d'une force manvaise -Michel Tournier

In the final scene of Michel Tournier's postcolonial novel La Goutte d'or (1986), the protagonist, Idriss, shatters the glass of a Cristobal \& Co. storefront window while operating a jackhammer in the working-class Parisian neighbourhood on the Rue de la Goutte d'or. ${ }^{1}$ Glass fragments scatter as the Parisian police arrive. As the novel comes to a close with the image of Idriss's pending arrest, the reader cannot help but reflect upon how the symbolism expressed by the shattered glass in this final scene underscores the very notion that the protagonist's identity, too, may be shattered or fragmented. In La Goutte d'or, Tournier explores the identity construction of Idriss, a Berber shepherd boy, through a discussion of the role that visual images play in the development of a twentieth-century consciousness of the "Other." At the beginning of the novel, a French tourist takes a photograph of Idriss during her visit to the Sahara. The boy's quest to reclaim his stolen image leads him from the Sahara to Marseille, and finally to the Rue de la Goutte d'or in Paris. ${ }^{2}$ The Goutte d'Or ("golden droplet"), known throughout Paris for its open-air market, the marché Dejean, is located east of Butte Montmartre (18th arrondissement). The Rue de la Goutte d'or remains one the most cosmopolitan neighbourhoods of the city. For Parisians, the Rue de la Goutte d'or has a symbolic value as well, for it is the centre of the district where North African immigrant workers often live in squalor and work in menial, labour-intensive jobs, such as garbage collection and street sweeping (Bacque 1-18). In Tournier's novel, the goutte d'or also corresponds to a symbolic object: a Berber jewel. It is the jewel that Idriss brings with him, but which he also subsequently loses upon his arrival in Marseille. From the very moment that the French tourist photographs him, a marginalization of Idriss's identity occurs. Marginality, quite literally, refers to the spatial property of a location in which something is situated. Figuratively speaking, marginality suggests something that is on the edges or at the outer limits of social acceptability. In this essay, I explore the construction of the marginalized postcolonial self (the "Other") through an examination of the function

1 All English-language translations of Michel Tournier's La Goutte d'or and other scholars are those of the author of this essay. Any shortcomings in this essay are mine.

2 In his article entitled "Photography at Odds with Reality in Michel Tournier's La Goutte d'or," Didier Bertrand maintains that "Idriss's quest of the photograph is narcissistic in nature and holds the key to a recovery of his lost oneness" (14). I disagree with Bertrand. Rather than narcissism, I would argue that Idriss experiences an identity crisis. 
of visual representation in the development of a postcolonial identity in $\mathrm{La}$ Goutte d'or. In the end, I conclude that the construction of a postcolonial identity is based upon fragmentation and marginalization, which ultimately leads its subject to create an identity based upon false constructions.

Tournier's novel is a journey of self-discovery which ascribes itself to Joseph Campbell's notion of the monomyth (1-37). Campbell states that

... a hero ventures forth from the world of common day into a region of supernatural wonder: fabulous forces are there encountered and a decisive victory is won: the hero comes back from this mysterious adventure with the power to bestow boons on his fellow man. (23)

Thus, when Idriss ventures to Paris to find the tourist who still holds his photograph, he begins a voyage of discovery in which he encounters a world that has created the division Orient/Occident. ${ }^{3}$ The Occidental world into which he enters is a world in which the visual image holds an unbelievable power. This world has the power to create the identity of its subject, to place its subject at the very centre or to relegate it to the margins (Petit 149-50). Idriss wanders in a maze of visual images created by Western civilization until the day that he ultimately finds his release through the discovery of calligraphy (the sign), the "Uncounterfeitable," which is the essence of Arab civilization. When Idriss arrives in Marseille and loses his golden droplet, this event which signifies a loss of his childhood innocence and his freedom ultimately foreshadows the difficulty that Idriss will have in creating his own identity as, throughout the novel, he will navigate through false visual images that extend from the Sahara to the streets of Paris which repeatedly serve to marginalize him. As Tournier illustrates, the golden droplet inherently represents nothing, for it is a pure sign symbolizing the abstract that ultimately resists fragmentation/marginalization.

Throughout La Goutte d'or, Tournier plays upon Jean Baudrillard's notion of a postmodern iconography. In his article "Simulacra, Symbolic Exchange and Technology in Michel Tournier's La Goutte d'or," David Price compares Idriss's journey of self-discovery to Baudrillard's four successive stages of the image. Price maintains that Tournier's novel presents "an exploration of an alternative to the sign economy" (350). Further, as Mary Vogl suggests,

... perhaps part of the ambiguity of Tournier's novel is that on one hand, as a writer, he believes in the power of the word but on the other hand he subscribes to the strain in Baudrillard's cultural metaphysics that ques-

3 Throughout this essay, I employ the terms Orient/East and Occident/West nearly interchangeably. 
tions the role of the intellectual and his or her self-image as a privileged agent for social change. (20)

Thus, if we consider Tournier's novel as a discourse between "the civilization of the image," Europe, and "the civilization of the sign," North Africa-in the Structuralist sense of the term (Culler 197-200) - any contradictions between what we think Tournier is saying in his text and what he actually says become insignificant.

Tournier's analysis of the role of the image serves to deconstruct the historic and ethnographic stereotypes of colonized peoples created within Western society (Platten 153). According to Edward Said, father of the seminal postcolonial theoretical text entitled Orientalism, "modern thought and experience have taught us to be sensitive to what is involved in representation, in studying the Other, in racial thinking, in unthinking and uncritical acceptance of authority and authoritative ideas" (327). ${ }^{4}$ Said maintains that the "Orient" is a fictional construct fashioned and forged under an external Occidental optic, which serves as an initially fragmented or marginalized identity. The "Orient" is a forgery created by Westerners in an effort to objectify peoples during the colonial enterprise. It is a forgery that continued to perpetuate itself in the neocolonial period and which continues to flourish in the $21^{\text {st }}$ century as well (Ashcroft 193-200). As Idriss begins to more fully understand how the fragmented, marginalized identity continually works against the authentic identity, ${ }^{5}$ he becomes progressively more capable of rejecting the stereotypes created by French society with the ultimate goal of forging his own identity by rejecting the concept of the "Other." Since the beginning of the French colonial experiment in the $19^{\text {th }}$ century, a discourse emerged that endeavoured to better understand the dichotomy that exists between the East and the West. Westerners continue to think of the East as the "Other" of the West, an untamed, exotic landscape. Literature, art, film, and political writings have perpetuated and disseminated stereotypes of North Africans (Armes 3-20). Western culture has exploited these stereotypes and taken advantage of these forgeries both to increase its own political authority throughout the world as well as to keep its subjugated peoples under its continual cultural control. No medium has propagated stereotypes more frequently than the visual medium.

4 Said's text provides what is the very core of the postcolonial perspective. Without a basic understanding of the "Other," the reader's attempt to understand the central themes of Tournier's novel becomes nearly impossible.

5 The notion of an authentic identity is one which poses its own philosophical questions. Is an authentic identity even a theoretical possibility? Do all human beings not, in some way, assume identities which others have created? How, then, can one forge an authentic identity? This essay, therefore, must acknowledge this potential paradox. 
Since television went mainstream in the 1950s, the function of the visual image has increased immeasurably. Multimedia, best evidenced through television, film, video games, the World Wide Web and social networks continue to exert a powerful presence in our daily lives. Among the visual media, however, photography remains arguably the most powerful means of visual representation because it presents images that the spectator believes to be authentic. Photography has both the power to create an optical representation and the ability to falsify the same image that it had set out to create. The images that we see form our world(view). These representational images aid in the creation of our identities as well. Individuals in both traditional and in modern societies struggle to forge their own representational identities, while at the same time working both in concert with and in opposition to any identities that exist on a national level. In France, slogans such as "Vive la République" and "Nos ancêtres, les Gaulois" emerged at critical moments in France's history in order to define the essence of a people. Each citizen began to perceive himself not so much as an individual, but rather as an extension of the homeland, losing a bit of the individual identity each time that he began to identify to a greater extent with the nation. Slogans of national identity, in fact, often create false identities or stereotypes of individuals that live within what are often extremely diverse societies. To state that all French citizens share the Gaulois as ancestors, for example, would not only be blatantly incorrect, but it would also marginalize the true individual and collective identities of many French who are descendants of other tribes, those of Germanic descent, Sub-Saharan African or North African descent, Vietnamese, Eastern European, etc., which, in the current era, calls into question the very notion of francité. ${ }^{6}$ In Tournier's novel, Berber identity itself is repeatedly misunderstood and misrepresented. As Jane Goodman explores in Berber Culture on the World Stage: From Village to Video, the Berber peoples themselves have multiple identities which are often inaccurately depicted by visual media throughout the world (49-68, 185-87). Instead of claiming such inaccurate and marginalized identities for themselves, Goodman advocates looking at Berber culture through an internal gaze. This internal gaze "is informed by neither the East nor the West but by indigenous modes of knowledge" (49). Such a perspective, therefore, becomes "a kind of bifocal vision, through which Berber culture [can be] brought into new focus by being set in relation to distant geopolitical events and entities" (50). It is this perspective which Idriss must adopt if he is ever able to cast aside the fragmented identity that is thrust upon him.

6 According to the Robert dictionary, the French Ministry of Culture created the word "francité" in 1965 to refer to "characteristics unique to French culture." 
Further, the dialectic between the image and the sign as depicted in La Goutte d'or underscores fundamental differences that exist between the Christian culture of the former and the Muslim civilization of the latter vis-à-vis the construction of an identity. Represented by the young Berber shepherd Idriss, which Tournier employs to stereotypically embody the marginalized Berber identity, this Muslim culture refuses both external definition and self-identification through the image, preferring direct access to true essence via the sign (Petit 151). In Idriss's village, the oasis of Tabelbala, its inhabitants gravely fear the image, for they believe that the power to duplicate any image comes from the Devil himself. On that fateful day when the blonde French tourist photographed the fifteen-year-old shepherd boy, she created a schism in the identity of the subject; a fragmented identity was created. Though she promised him that she would send a copy of his snapshot to him, said copy never arrived. As readers, we understand that to place the photograph within the young boy's hands would ultimately give him both creative power and control of his own identity/destiny. Such a gesture would necessarily fracture the dialect that exists between the "colonizer" and the "colonized," this mutually dependent relationship of oppression that must be constantly repeated in order to eventually selfperpetuate. To place the photograph in Idriss's hands would, in one fell swoop, destroy the oppression initiated under the "mission civilisatrice" of France, which had continued in the neocolonial period.?

It is worth noting that photography and oppression bear a striking lexical relationship. In On Photography, Susan Sontag underscored the fact that through its terminology, photography is linked to oppression, for the medium employs a vocabulary associated with hunting: "load," "aim," "shoot" (14). Though this comparison is extreme, if considered exclusively within a metaphorical sense, the two are, in fact, analogous. Sontag adds: "There is an aggression implicit in every use of the camera ... To photograph people is to violate them" (7). Photography "turns people into objects that can be symbolically possessed" (14). More importantly, the photographer produces an image that can be manipulated ad infinitum. Copies of images can be copied as well, creating yet another abstraction. To photograph someone is to possess them metaphorically, to such an extent that the individual is deprived of any real human value. The objective lens of the camera figuratively "captures" the essence of the subject, thus robbing the latter of any realness. This notion is particularly true within the colonial context in which the conquest through the image mirrors the conquest of a people, as Nissan

\footnotetext{
"Mission civilisatrice" served as a rationale for colonization which resulted in the Westernization of indigenous peoples. This rationale became the governing principle of French colonial rule in Africa from the late 19th century to the middle of the 20th century.
} 
Perez underscores: "The extensive photographic activity in the Orient was, indeed, an act of aggression - if not a physical occupation, a spiritual appropriation of those lands" (100). ${ }^{8}$ To the Berber people, however, this is a fact that is very real. It is a fact of which the French photographer is completely unaware and something of which we, ourselves, are totally unaware when we take photographs of individuals without their permission. In contrast to the moving image, which trains us to look into "the depth of the shadows of history," Walter Benjamin theorizes that the photographic image encourages absorption (qtd. in Mitrano 4). Further, according to G.F. Mitrano, "photography inaugurates a new glance-one that sees the 'here and now' that sears the subject in the still image - that supersedes the narrative of the reciprocity of the gaze" (5).

Thus, the French photographer's potentially manipulative gaze remains ubiquitous in La Goutte d'or: "Tu pourrais au moins lui demander son avis, grommela l'homme. Il y en a qui n'aiment pas ça" ("You might at least ask his opinion, the man muttered. Some of these people don't like it"; Tournier 13), as if her husband were conscious of his wife's domination over Idriss through the photograph. The French tourist immediately turns Idriss into a snapshot (cliché) that can be endlessly duplicated. Each copy further pushes Idriss to the margins of any possible authentic identity. For the tourist, this young shepherd boy is nothing more than part of the exotic North African landscape, a tree in the pays de rêves in which she has spent her vacation. Her photograph "très carte postale" corresponds precisely to the stereotypical representation of a North African boy, since she is not at all aware of the power that she holds over him by simply taking his photograph. This is the danger inherent within the neocolonial enterprise. It is the ignorance of the French tourist that risks compromising Idriss's "native identity." As long as Idriss remains unable to retrieve his photograph, he will be deprived of his essence, his soul, his very being. Indeed, "of all the images in the world, our own photographic portrait is the most important, for it constitutes the core of our existence" (Lapidus 7). ${ }^{10} \mathrm{In}$

8 It is important to understand the term "Orient" within the French perspective, as it is commonly used to refer to both Saharan and Sub-Saharan Africa. The terms "Maghreb," "Maghrébin," and "Maghrébine" are more commonly used within a North African context. See Nissan Perez's Focus East: Early Photography in the Near East (1839-1885) (New York: Abrams, 1988): 100-02.

9 Like the term "authentic identity," which I have used throughout this essay, I would like to suggest that there still remains a unique identity into which the individual is born. In this essay, I do not intend to use the word "native" as a synonym of "indigenous."

10 Because within Berber culture the portrait represents the subject's soul, one can see why taking a photograph without permission "dispossesses" the subject. See "A Dispossessed Text: The Writings and Photography of Michel Tournier," Trans. Roxanne Lapidus, SubStance 58 (1989): 27. 
Idriss's oasis of Tabelbala, there has only ever been but one photograph; that of his Uncle Mogadem, photographed with two friends during World War II. Uncle Mogadem always carried a copy of the photograph with him, for he thought that it brought him good luck. He believed, however, that his two friends died because he had not yet given their copies of the photograph to them: "Non tu vois. Les photos, faut les garder. Faut pas les laisser courir!" "'Our Photographs, you see-you must hang on to them. Must not let them go gallivanting"; Tournier 56). When our photographs wander, they become commonplace, and thus lose their value, their essence. When this occurs, we risk the fragmentation and marginalization of our very being. Idriss's quest to regain possession of his photograph and consequently, his soul and identity, leads to a long series of events during which he falls into the trap of false images that have created the stereotypes that have dominated the Berber people for centuries.

Even before Idriss leaves for France in search of his photograph, he had already become aware of the artifices associated with the image. When he receives a postcard with the picture of a donkey on it, all the inhabitants of his village ridicule him. Is this donkey (ass) the photographic reproduction of Idriss that was taken by the French tourist? Is this photograph a reflection of his existence (51-52)? Later, upon his arrival in Oran, a woman proposes him a good life if he agrees to assume the identity of her dead son, whose photograph Idriss only vaguely resembles: "Lui ressemblait-il vraiment? Idriss était hors d'état d'en juger, n'ayant qu'une idée vague de son propre visage" ("Did he really resemble him? Idriss was in no position to judge, as he had but a vague idea of his own face"; 93). A simple paradox explains Idriss's situation: he will be unable to create his own identity when he is continually having a marginalized one created for him which he, in fact, is able to use successfully. The fragmentations continue when Idriss has his photograph taken for the papers that he needs to enter France. While waiting for his photograph to be ejected from the automatic machine, he is quite surprised to see the face of a bearded man appear rather than his own face. Idriss's confusion is underscored in the question that the narrator poses: "Après tout pourquoi n'aurait-il pas eu une barbe avant de quitter Tabelbala? Les barbus ont aussi droit à un passeport" ("After all, why would he not have had a beard before leaving Tabelbala? Bearded men also have the right to a passport"; 85). This fragmented, marginalized identity represents a great challenge for Idriss to reconcile since, once again, he is able to successfully assume the identity of a bearded man. In the Occidental world, it seems that the only way that Idriss will be able to effectively navigate is by yielding to the stereotypes placed before him. Each of Idriss's trials, therefore, is a metaphor for the forgeries to which he must constantly conform. In a sense, no one that he encounters during his 
travels cares who be is. This notion is part and parcel of Tournier's principal theme on identity fragmentation and marginalization. The essence of the individual is inconsequential. Society's perception of the individual is the only perception that truly matters.

Therefore, Idriss has little choice but to surrender to the power of the image by assuming the identity of the bearded man. As his identity is fragmented, he is implicated, as well; he is forced to marginalize himself in order to obtain what he wants. Further, he is convinced that his true existence is worth nothing, for he is able to obtain his papers even with a photograph that is not his own. Didier Bertrand concludes that "the representation of self offered by the photographic image generally works as a mirror. Yet, in the case of Idriss, a very problematic bodyimage is consistently produced and actually leads the youth to yield to the representation" (14). In the Lacanian sense, Idriss's subject formation is a process. The "mirror stage," to which Jacques Lacan often refers, functions as a dialectic in which the "I" is identified by an understanding of the "Not I" (Homer 24-25). As is the case with Idriss, in Lacan's mirror stage, there is a movement from unity to fragmentation, from collective to individual. ${ }^{11}$ Eventually, there is an attempt to reintegrate to the collective, which we witness at the end of the novel, as Idriss will eventually be reintegrated within a North African district of Paris in the "Rue de la Goutte d'or." In short, the photograph of the bearded man, in particular, fragments Idriss's identity, representing the "Not I" of Idriss's existence. Although the photograph cannot make him French in any sense of the term, it functions to "normalize" Idriss by assuring that he both represents and perpetuates the stereotype that the French have created for a North African immigrant. In a sense, Idriss becomes North African-in the French sense of the term-at the very moment that he is profiled, photographed, and classified according to the Occidental definition of what constitutes a member of this particular ethnic group. According to Vincent Colapietro,

... in addition to the external Other, there exists another one, the internal other "self" created by the passing of a sign into an interpretant, interpretant into sign, and the self of one moment into the self of another moment. The radical absence of the self from its other self, semiotically

11 With regard to a Lacanian analysis of Tournier's novel, several interesting questions arise. Firstly, is it theoretically possible to actually lose an identity, to have it stolen, or even to regain it? Or does such a notion function purely metaphorically here? Further, is it theoretically possible to quantify or to qualify "identity"? If so, how would one describe it or measure it? If one can neither qualify nor quantify "identity," then does it really even exist at all? 
evidenced by shifters, creates not a stable but a restless semiosis incessantly sliding along the slope of signification. (40)

For Jacques Derrida, in contrast, such marginalization is due to the loss of presence that is so intrinsic to the operation of the sign, and most evident within the written sign. Further, Derrida speaks of a transcendental signified, in which he appropriates Ferdinand de Saussure's term "signified." He suggests that it is the indefiniteness of reference that brings the tradition of metaphysics to desire the transcendental signified so intensely, while repressing its absence so vigorously (qtd. in Colapietro 367). A Derridean analysis certainly applies to Idriss's situation as the latter struggles to interpret the signs placed before him.

When Idriss finally arrives in Paris, still in search of his lost photograph, he meets a man named Milan who is a manufacturer of mannequins of young boys. Milan's business reflects a double-fragmentation of the image. Firstly, mannequins are nothing more than replicas of human beings. Secondly, Milan photographs his mannequins:

Quant aux mannequins, étant eux-mêmes déjà les images, leur photo est une image d'image, ce qui a pour effet de doubler leur pouvoir dissolvent. Il en résulte une impression de rêve éveillé, d'hallucination vraie. C'est absolument la réalité sapée à sa base par l'image. (181)

As for mannequins, since they themselves are already images, their photograph is an image of an image, and this has the effect of doubling their dissolving power. The result is an impression of a waking dream, a genuine hallucination. It is reality undermined at its very foundations by the image.

The fragmentation of the fragmented image does not represent the identity of its subject in any way. It lacks authenticity.

Ultimately, Idriss begins to work as a model for the fabrication of polyester mannequins for the store windows of Tati. When he goes to the gyptoplastic workshop to have a mould of his body created, Tournier underscores the highest evil of identity fragmentation. Recreated in alginate, the mould of Idriss's body becomes the ultimate means to perpetuate the stereotype of a young North African. Without even realizing it, Idriss has now completely lost his identity, for now his lifeless image will be duplicated and re-duplicated endlessly. As Pary Pezechkian explains: "Toutes les images qu'Idriss rencontre sur sa route essaient de le faire rentrer dans un moule préétabli, une image, un référant qu'ils reconnaissent et qui lui est totalement inconnu et étrange" ("All the images that Idriss meets on his 
way attempt to make him fit into a prescribed mould, an image, a referent that they recognize and which is completely unknown and foreign to him"; 3). Finally, when Idriss goes to the zoo and enters a Hall of Mirrors, he

... s'observe gonflé comme un ballon, ou au contraire filiforme, ou coupé en deux au niveau de la ceinture. Il tire la langue à ces images grotesques de lui-même qui viennent s'ajouter à tant d'autres. Un concert de rire frais lui répond. (159)

... observes himself puffed up like a balloon, or on the contrary tall and skinny, or cut in half at the waist. He sticks out his tongue at these grotesque images of himself, the latest additions to so many others. A concert of youthful laughs answers him.

The scene of the hall of mirrors is a metaphor for the tests that Western civilization makes Idriss endure (Pezechkian 6). In this Lacanian flashback, this mirror shows Idriss's image as constructed and perceived by Occidentals, stretched and pulled to fit a predetermined European definition. Each image of Idriss which surfaces represents yet another attempt to forge something new, but like the ebb and flow of the sea on a beach, what the sign creates the image erases at the same time. Working against all of these obstacles, how can Idriss succeed in constructing his own authentic identity? How will he not ultimately drown in this sea of false images?

The restoration of Idriss's Berber "native identity" begins at the moment that he meets a master calligrapher who teaches him to exchange the marginalizing power of the image for the liberating purity of the sign. Idriss finally understands that all of the images of himself that he had seen during his voyage from the Sahara to Paris were deceptions, the counterrealities of his true being. In calligraphy, where the liberating purity of the sign flourishes, Idriss finds the dimensions of his existence-his authentic identity - which he had never before seen, but which were always present in his Saharan oasis:

Dès sa première calligraphie, Idriss se retrouva plongé dans le temps démesuré où il avait vécu sans le savoir à Tabelbala. Il comprenait maintenant que ces vastes plages de durée étaient un don de son enfance, et qu'il les retrouverait désormais par l'étude, l'exercice et le désintéressement. D'ailleurs la faculté offerte au calligraphe d'allonger horizontalement certaines lettres introduit dans la ligne des silences, des zones de calme et de repos, qui sont le désert même. (199)

From his very first calligraphy, Idriss found himself plunged back into the time beyond measure when he had lived without knowing it in Tabelbala. He now understood that those vast stretches of duration were 
a gift of his childhood, and that from now on he would regain them by study, practice, and disinterestedness. And besides, the faculty given to the calligrapher to lengthen certain letters horizontally introduces silences into the line, zones of calm and repose, which are the desert itself.

Calligraphy illustrates the importance of the sign as a means of release from visual representations, underscoring the contrast that exists between representation (image) and interpretation (sign). Thus, at the end of his novel, Tournier's message becomes clear. The only way to escape the evil power of the image is through writing. Illiterates like Idriss fall into the traps placed by images, for they do not have the wisdom that is needed to decipher them. ${ }^{12}$ Their identities are fabricated because they are unable to release the liberating power that has dwelled within them all the while. The literate individual "reads" images. This individual has the ability to create and to reject the artificial nature of the image. Through the sign, the individual will find freedom, but through the image there is only imprisonment:

Ces adolescents musulmans plongés dans la grande cité occidentale subissaient toutes les agressions de l'effigie, de l'idole, et de la figure. Trois mots pour désigner la même asservissement. L'effigie est verrou, l'idole prison, la figure serrure. Une seule clef peut faire tomber ces chaînes: le signe.... en vérité l'image est bien l'opium de l'Occident. (201-02)

These Moslem adolescents, submerged in the big occidental city, were subjected to all the assaults of the effigy, the idol, and the figure.... The effigy is a door bolt, the idol a prison, the figure a lock. Only one key can remove these chains: the sign. ... The image is truly the opium of the Occident.

Therefore, the literate individual knows how to deconstruct and decode images in order to forge an authentic identity. In a sense, the image must be translated into a rhetorical figure. Tournier suggests that if Idriss had been literate, his knowledge and wisdom would have sheltered him from the evil power of the image. His mind would have been open and free. When he is finally able to escape the marginalizing power of the image at the end of the novel, Idriss embraces the liberating power of the sign and he is freed from the Occidental stereotypes associated with his North African existence. He is now able to forge both his own authentic identity and, as a result, his own destiny as well.

12 Tournier's novel certainly suggests that education is the key to leading oppressed peoples to freedom. 
As noted in the introductory paragraph of this essay, in the final scene of the novel, Idriss is operating a jackhammer, the symbol of the Maghrebine worker, another cliché of the North African living in the Rue de la Goutte d'or in Paris, in the Place Vendôme. He is very content to have mastered this tool, "sa partenaire de danse" ("his dance partner"; 220). In the window of a corner jewellery store, Idriss sees a golden droplet on a black velvet cushion. Is this the golden droplet that he had lost in Marseille? His jackhammer penetrates the window and the store alarm sounds. Idriss does not hear the alarm, the noise of the shattering glass aurally signifying his "breaking free" of the bonds of the image. Looking at the golden droplet, Idriss has found the pure sign, the absolute form, the symbol of freedom, the key that will permit him to leave this prison of false images and create his own authentic identity. Has he succeeded in rejecting the marginalized postcolonial self (the "Other") which is created through the power of visual representation? Although Tournier seems to leave the door open a bit, I would suggest that Idriss has, at minimum, begun an early step in rejecting a postcolonial identity based upon fragmentation and marginalization which had initially lead him to assume an identity based exclusively upon false constructions. If we believe Tournier's narrator who claims that "l'image est douée d'une force mauvaise" ("the image is endowed with evil power"; 100), then we might conclude that the only way that Idriss can escape its evil power is by making both a concerted and a conscious effort to continually reject the false identities cast upon him by the image. Then, and only then, might he succeed in truly wearing the "goutte d'or," the sign of a free existence.

\section{Works CITED}

Armes, Roy. African Filmmaking: North and South of the Sabara. Bloomington: Indiana UP, 2006. Print.

Ashcroft, Bill, Gareth Griffiths, and Helen Tiffin. The Empire Writes Back: Theory and Practice in Post-Colonial Literatures. London: Psychology, 2002. Print.

Bacque, Marie-Hélène, et al. "Social Mix Policies in Paris: Discourses, Policies and Social Effects." International Journal of Urban and Regional Research 35.2 (2011): 1-18. Print.

Bertrand, Didier. "Photography at Odds with Reality in Michel Tournier's La Goutte d'or.” Romance Languages Annual 7 (1995): 13-17. Print.

Buisine, Alain. "A Dispossessed Text: The Writings and Photography of Michel Tournier.” Trans. Roxanne Lapidus. Sub-Stance 18:1 (1989): 25-34. Print. 
Campbell, Joseph. The Hero with a Thousand Faces. Novato: New World Library, 2008. Print.

Colapietro, Vincent Michael. Peirce's Doctrine of Signs: Theory, Applications, and Connections. Berlin: de Gruyter, 1996. Print.

Culler, Jonathan. Structuralist Poetics. Ithaca: Cornell UP, 1975. Print.

Goodman, Jane E. Berber Culture on the World Stage: From Village to Video. Bloomington: Indiana UP, 2005. Print.

Homer, Sean. Jacques Lacan. New York: Routledge, 2005. Print.

Mitrano, G.F. "The Photographic Imagination: Sontag and Benjamin.” Post Script 26.2 (2007): 117-36. Print.

Perez, Nissan. Focus East: Early Photography in the Near East (18391885). New York: Abrams, 1988. Print.

Petit, Susan. Michel Tournier's Metaphysical Fictions. Philadelphia: Benjamins, 1991. Print.

Pezechkian, Pary. "La Goutte d'or de Michel Tournier: pour une rhétorique de l'image." Francographies: Bulletin de la Société des Professeurs Français et Francophones D'Amérique 1 (1993): 1-6. Print.

Platten, David. Michel Tournier and the Metaphor of Fiction. New York: St. Martin's, 1999. Print.

Price, David. "Simulacra, Symbolic Exchange and Technology in Michel Tournier's La Goutte d'or." Studies in Twentieth Century Literature. 17:2 (1993): 349-63. Print.

Said, Edward. Orientalism. New York: Vintage, 2005. Print.

Sontag, Susan. On Photography. New York: Dell, 1978. Print.

Tournier, Michel. La Goutte d'or. Paris: Gallimard, 1986. Print.

Vogl, Mary B. Picturing the Maghreb: Literature, Photography, (Re)Presentation. Lanham: Rowman, 2002. Print.

Wolf, Mary Ellen. “The View from the Street: La Goutte d'Or.” Journal of International Women's Studies 6.2 (2005): 202-07. Print. 